\title{
IX. On the teeth of fishes, and shells found in the vicinity of Reading
}

\section{Plenderleath M.D.}

To cite this article: D. Plenderleath M.D. (1813) IX. On the teeth of fishes, and shells found in the vicinity of Reading , Philosophical Magazine Series 1, 41:177, 44-46, DOI: $10.1080 / 14786441308638702$

To link to this article: http://dx.doi.org/10.1080/14786441308638702

里 Published online: 27 Jul 2009.

Submit your article to this journal $₫$

Џ Article views: 2

Q View related articles $₫$ 
to ascend to the philosophy of those Greeks who were an honour to the art. This state of things continued to the present day, and the conventions of the mannerists had all the force of law in the workshops. All the talents of an infinite number of painters, very jirstly admired, do not destroy their opinion. It was reserved to nur ara, and our schools, to abandon and annibilate prejudices so long combated without success. Painting and sculpture, alarmed and ashamed at so many humiliating degradations, finally threw themselves into the arms of nature: artists again resumed the route which she pointed out.

[To be continued]

IX. On the Teeth of Fishes, and Shells found in the Vicinity of Reading. By D. Plenderleath, M.D., Reading.

\section{To Mr. Tilloch.}

$S_{I R}, I_{N}$ the vicinity of Reading, within a circumference of three miles, there are four brick manufactories. The pits which have been dug for the purpose of procuring materials for the formation of bricks, afford an opportunity of examining the strata of earth in this vicinity; and of however small importance individual observations of themselves may be-still, in a collective point of view, they may add to a mass "of evidence which may eventually lead to the most interesting irrductions in the science of mineralogy.

The celebrated Cuvier, in his la expublication on Organic Remains in the vicinity of Paris, has by patient investigation and indefatigable industry thrown considerable light on this subject. Disclaiming all speculative opinions, he has continued by nnwearied application to examine nature herself; and has described the appearances which presented themselves, in plain and perspicuous language, avoiding as much as possible those technical terms which may have a reference to former and probably erroneous systems; for the knowledge of the constituion of the earth is still in its infancy, and it is only to be forwarded by the means which he has pursued. In reference to this opinion, I transmit to you for insertion in the Philosophical Magazine, the following appearances from actual observation of the pits above described. The greatest in depth does not ex ceed eighty feet from the surface to the bottom; and as they all coincide pretty exactly in the nature of their stratification, I shall select that one which has been longest opened, 
and in which the greatest number of teeth and shells has been discuvered, for description. The layers are all horizontal, and the section is vertical. The first, layer, and which is the foundation, is chalk. In this formation no organic remains have been discovered; it contains nodules of flints, which are usually in beds and adhering to the chalk. Immediately above is the stratum of sand, containing the remains of marine animals. Its thickness varies from two feet and a half to less than a foot. The bed containing these remains is not entirely of sand, as some clay may be distinguished among it. The ovsters are commonly entire; one valve being connected with another, although the adhesion has become so slight that they may without difficulty be separated, and the laminæ of each valve may likewise be very easily divided. On separating the valves, I found that the place which had been occupied by the oyster was filled by an unctuous earth exactly of the same shape with the oyster.

The external appearance of these shells is in some instances entire; but they generally have the appearance of those oyster shells which have been exposed to beat, and when placed in a fire they do not crepitate. The nuter surfaces are rough; the inner smooth. They differ very much in size. The largest which I have observed is six inches in length and four in breadth. That they exist in very considerable quantity is proved from the circumstance of their having been discovered for upwards of a century, since which tume the workmen have beew in the daily ctustom of finding them. Dr. Brewer, in the Plitosophical Transactions for 1700 , mentions them without adverting to the teeth which are found in the same formation. These teeth are of a triangular shape, a little bent, of a darkleaden colour, and having their surfaces polished. They are vury small, the longest not much exceeding an inch in length, with the interior surface in some longitudinally sulcared. They are found in considerable quantities, but no vertebræ or any other remains of marine animals have been discovered along with them. The land in which they are imbedded is coarscr and of a darker colour than that which is superincumbent, containing a little clay and gravel; which I remark, becarse, in order to obtain any usefil knowledge on these subjects, it is necessary that the examination of these bodies should be connested with that of the strata in which they are found. The next stratum is a thin one of blue-coloured earth, above which is a layer of sand without any adhesion of extraneous substances, and extending 
to the thickness of seven feet. The next in succession is the formation of red clay, which is communly the greatest in thickness of the formations. The last and uppermost is the alluvial earth, which does not exceed the thickness of two feet. In the three other pits, the difference consists in the relative thickness of the different strata. In the one which is most advanced in a northern direction, the shells are wanting; hut teeth, similar to the others, are discovered.

I may likewise mention that a vertical section, made within the extent of a mile from this northernmost pit, affords a quite different appearance of the stratification, as immediately under a thin covering of alluvial earth is chalk, which presents a singular appearance, the layers of chalk and of flints being alternate through the whole depth, and observing great regularity of distance. The Thames divides these two pits.

Many paits in this island afford opportunities of describing differences in stratification; and when many such surveys are made in parts of the globe separated from each other, and these appearances accurately conpared, there is no doubt but that a true theory of the mineral kingdom will be the result.

$$
\begin{aligned}
& \text { I am, sir, } \\
& \text { Your obedient humble servant, } \\
& \text { Reading, Jan. 21, 181s. } \\
& \text { D. Plende RLEATH, M. D. }
\end{aligned}
$$

X. Notices respecting New Books.

Interesting Discoveries and Researches on the Foot of the Horse. By Bracy Clank, F.L.S. \&xc. In two Parts. Quarto.

A mong other discoveries contained in this work are:The inflexion of the hoof at the heels, towards its centre, forming an elastic bow, important in diminishing the resistance to the weight and efforts of the animal :-A remarkable band discovered, passing from the sides of the frog round the upper part of the hoof, serviug to connect it strongly with the skin, and to close the line or joint where they incet.

The real cause of the running thrush is explained on principles before unknown.

A most important defect detected, in the principle itself, of madern shoeing, more injurious than the abises complained of, particularly to growing feet, and the elastic feet of bloud horses, demonstrated by a striking and very de- 